\title{
12
}

\section{Evaluation of the Thermal Impact of Stormwater Management Ponds}

\author{
Farshid Sabouri, Bahram Gharabaghi, Nandana Perera and Ed \\ McBean
}

Stormwater management ponds (SWMPs) remain a popular option to control flood damage, and for the effective removal of suspended solids and associated contaminants from urban surface runoff (Anderson et al., 2002; Marsalek et al., 2002). However, such ponds can produce diverse potentially negative thermal effects on aquatic habitat (Herb et al., 2009; Lieb et al., 2000; Scheueler and Galli, 1992). The construction and use of SWMPs is increasing in the rapidly developing urban areas of southwestern Ontario, and several municipalities have hundreds of SWMPs within a single watershed. The potential impacts of SWMPs are clearly significant.

This study was developed because of the recognition of the lack of sufficient information and data in Ontario with respect to the potentially adverse thermal enrichment effect of SWMPs on sensitive aquatic habitat. The need for a design of cooling trenches to mitigate the potential adverse effects of SWMPs, and the effectiveness of those cooling trenches which have already been constructed, were other motivators for this study. Furthermore, very few studies and data are available in Ontario on the temperature monitoring of existing ponds and their cooling trenches.

The purpose of this study is to investigate the thermal effects of traditional SWMPs in southern Ontario climate conditions and to evaluate the thermal impact of these SWMPs. The evaluation includes an examination of the effects of upland area characteristics on thermal enrichment and of the effectiveness of current thermal mitigation methods, such as bottom draw outlets and constructed cooling trenches. The preliminary results of the monitoring program are presented in this chapter.

Sabouri, F., B. Gharabaghi, N. Perera and E. McBean. 2013. "Evaluation of the Thermal Impact of Stormwater Management Ponds." Journal of Water Management Modeling R246-12. doi: 10.14796/JWMM.R246-12. (C) CHI 2013 www.chijournal.org ISSN: 2292-6062 (Formerly in Pragmatic Modeling of Urban Water Systems. ISBN: 978-0-9808853-8-5) 


\subsection{Methodology}

\subsubsection{Introduction}

Urbanization causes temperature increases in stormwater runoff. Asphalt and other impervious surfaces absorb heat energy and during rainfall events the stored heat is transferred to the runoff, which eventually discharges to a water body (Thompson et al., 2008). Water temperature is a critical environmental factor for cold water fisheries because most aquatic organisms have a specific temperature range that they can tolerate (Booth and Bledsoe, 2009). Thermal pollution can also affect the ecological functions of aquatic species such as spawning and growth (Selong et al., 2001; Armour, 1991).

Stormwater management ponds remain a popular option to control runoff, total suspended solids (TSS) and pollution, among other practices. However, SWMPs can have a thermal impact. This study has been developed in response to the recognition of the lack of sufficient information and data in Ontario with respect to potential adverse thermal enrichment of SWMPs on sensitive aquatic habitats.

\subsubsection{Study Description}

In this study, six SWMPs were monitored during three summers (2009 to 2011). The locations of the ponds, in Guelph and Kithcener, Ontario are shown in Figures 12.1 and 12.2 and given in Table 12.1

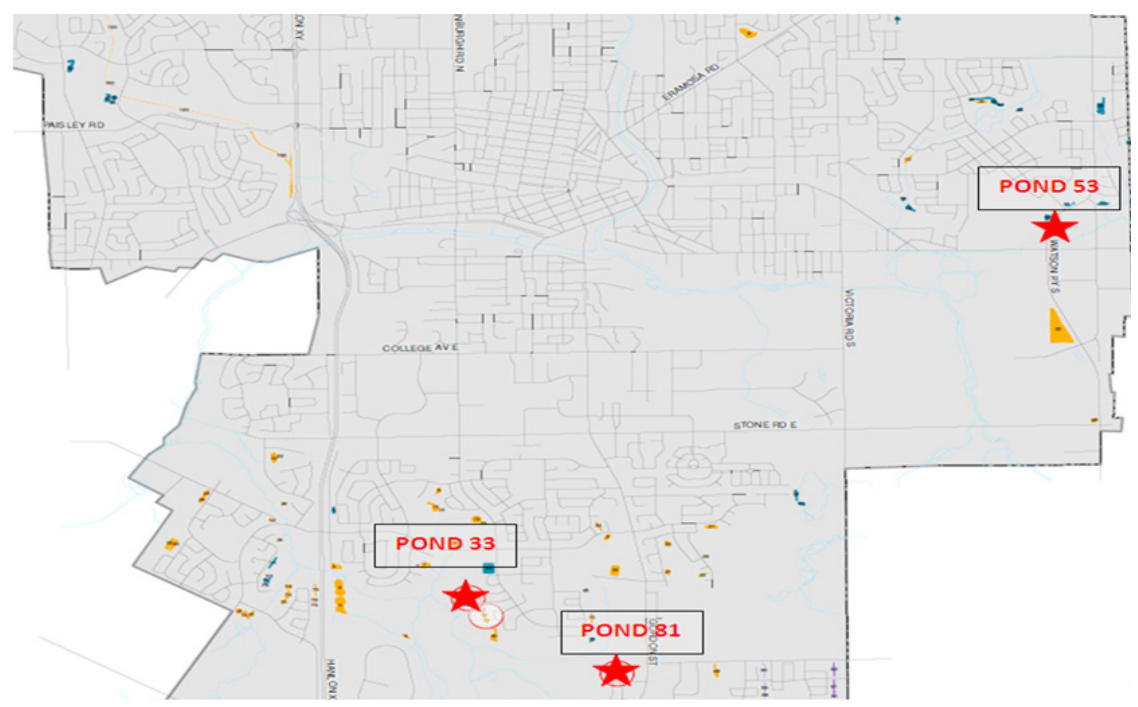

Figure 12.1 Locations of Guelph ponds. 


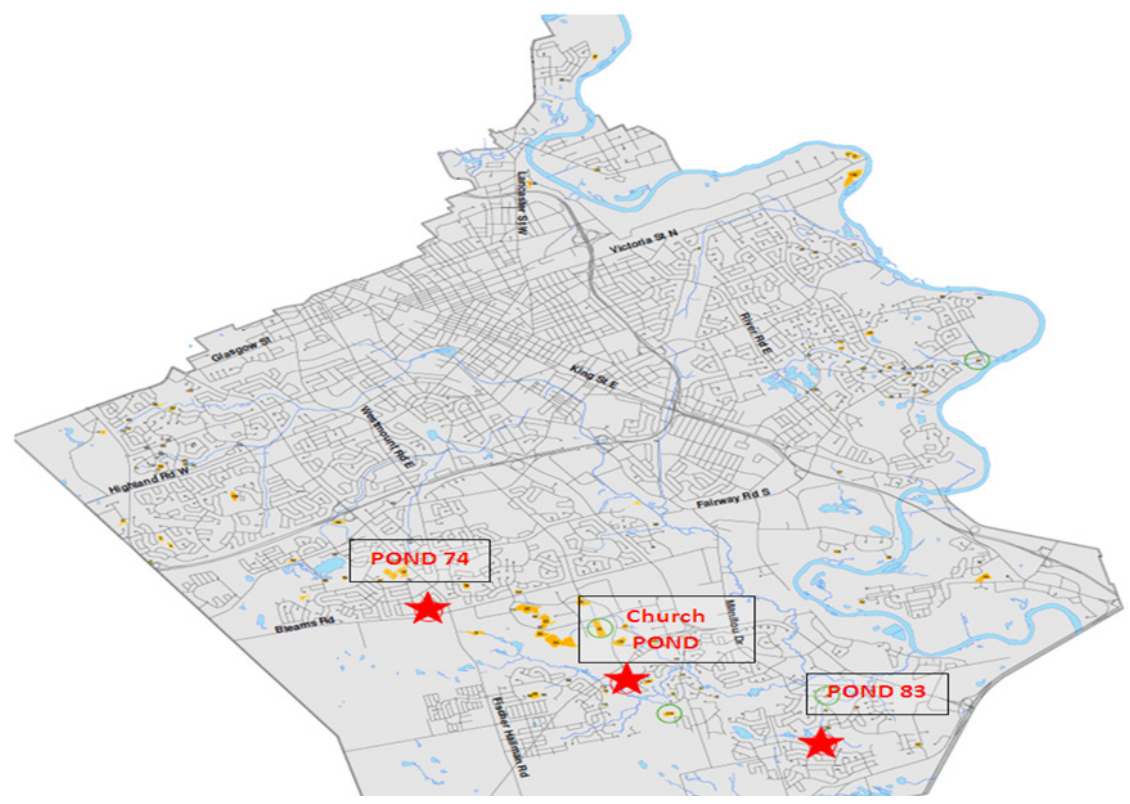

Figure 12.2 Locations of Kitchener ponds.

Table 12.1 Pond locations.

\begin{tabular}{lll}
\hline \multicolumn{1}{c}{ Pond } & \multicolumn{1}{c}{ City } & \multicolumn{1}{c}{ Location or Major intersection } \\
\hline 53 & Guelph & York Road and Watson Road \\
33 & Guelph & Edinburgh Road South and Southcreek Trail, next to Preservation Park \\
81 & Guelph & Edinburgh Road South and Gordon Street, East of Carrington Drive \\
74 & Kitchener & The northwest corner of Bleams Road and Fischer-Hallman Road \\
83 & Kitchener & Robert Ferrie SWM (Topper Swamp-West pond), Robert Ferrie Drive \\
Church & Kitchener & 1880 Strasburg Road (private facility) \\
\hline
\end{tabular}

The Guelph ponds have catchment areas of 79 ha, 19.4 ha and 5 ha for pond 53, pond 33 and pond 81 respectively. The Kitchener ponds are pond 74, pond 83, and Church with drainage areas of 35.8 ha, 10.8 ha, and 5.1 ha respectively. Surface areas and volumes of the ponds are given in Table 12.2. The receiving system for ponds 33 and 81 in Guelph is the Hanlon Creek and for pond 53 is Clythe Creek. Water from pond 74 in Kitchener discharges to the wetland next to it and the receiving systems for pond 83 and Church are Doon South Creek and Strasburg Creek respectively. Furthermore, ponds 53, 81, 74 and Church have had cooling trenches which were monitored during the course of the study. 
Table 12.2 Pond information.

\begin{tabular}{ccccc}
\hline Pond & $\begin{array}{c}\text { Catchment area } \\
(\mathrm{ha})\end{array}$ & $\begin{array}{c}\text { Volume } \\
\left(\mathrm{m}^{3}\right)\end{array}$ & $\begin{array}{c}\text { Surface area } \\
\left(\mathrm{m}^{2}\right)\end{array}$ & Surface area/Catchment area \\
\hline 53 & 79 & 6440 & 8400 & 0.011 \\
33 & 19.4 & 4000 & 6800 & 0.035 \\
81 & 4.9 & 406 & 330 & 0.007 \\
74 & 35.8 & 5376 & 4000 & 0.011 \\
83 & 10.8 & 1300 & 1387 & 0.013 \\
Church & 5.1 & 950 & 2165 & 0.042 \\
\hline
\end{tabular}

The collected data from sensitive zones (inlet, inside the pond close to outlet, outlet, and inside the cooling trenches) are used to evaluate the performance of the ponds. A PCSWMM model was developed to mimic the existing hydrologic conditions of the catchment areas in Guelph and Kitchener. The land uses within the catchments and the drainage areas vary from pond to pond.

The model was developed from the photogrammetric data and maps representing the studied areas with the use of GIS tools. The pond water level data which have been monitored in the course of study were used to calibrate the PCSWMM model for existing conditions. The inflow and outflow time series generated by PCSWMM was used to calculate event mean temperatures (EMTs) through the system using Equation 12.1 (Picksley and Delectic, 1999). To calibrate the model using the measured water level of ponds, ponds water level time series created by PCSWMM were compared with the measured data to get the best fit as is shown in figure 12.7 below. The Guelph Turfgrass Institute and the Grand River Conservation Authority (GRCA) monitoring stations provided the required climatic data. The Guelph ponds drainage areas are shown in Figures 12.3 through 12.5 opposite.

$$
E M T=\frac{\sum_{i=1}^{n}(\text { QTempdt })}{\sum_{i=1}^{n}(Q d t)}
$$

where

$$
Q=\text { the runoff discharge }\left(\mathrm{m}^{3} / \mathrm{s}\right),
$$

Temp $=$ the runoff temperature $\left({ }^{\circ} \mathrm{C}\right)$,number of time seps

$d t=$ the time increment of $10 \mathrm{~min}$, and

$n=$ number of time steps. 


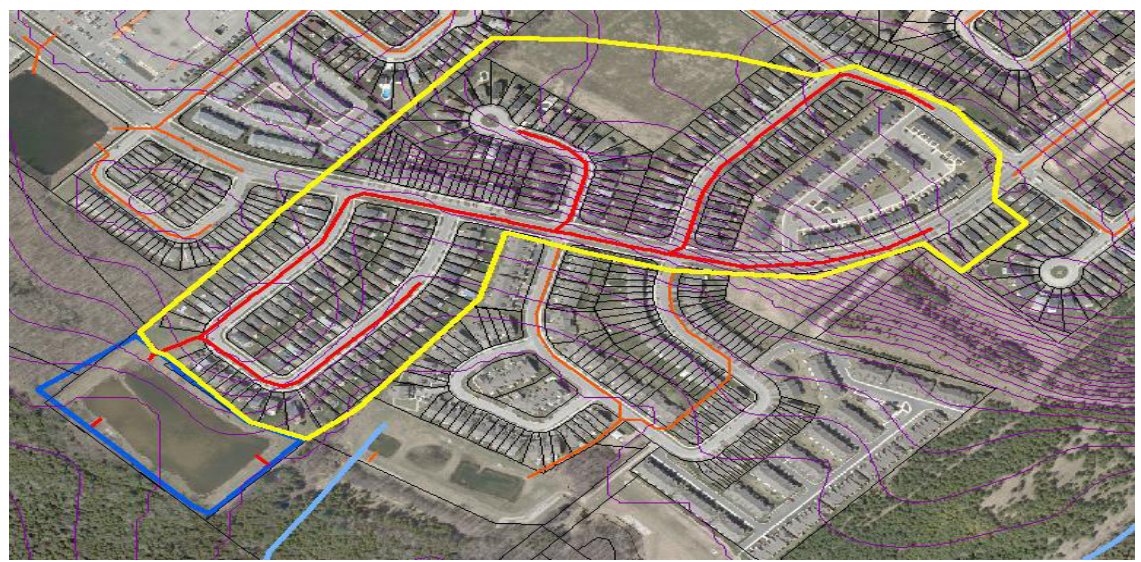

Figure 12.3 Pond 53 drainage area.

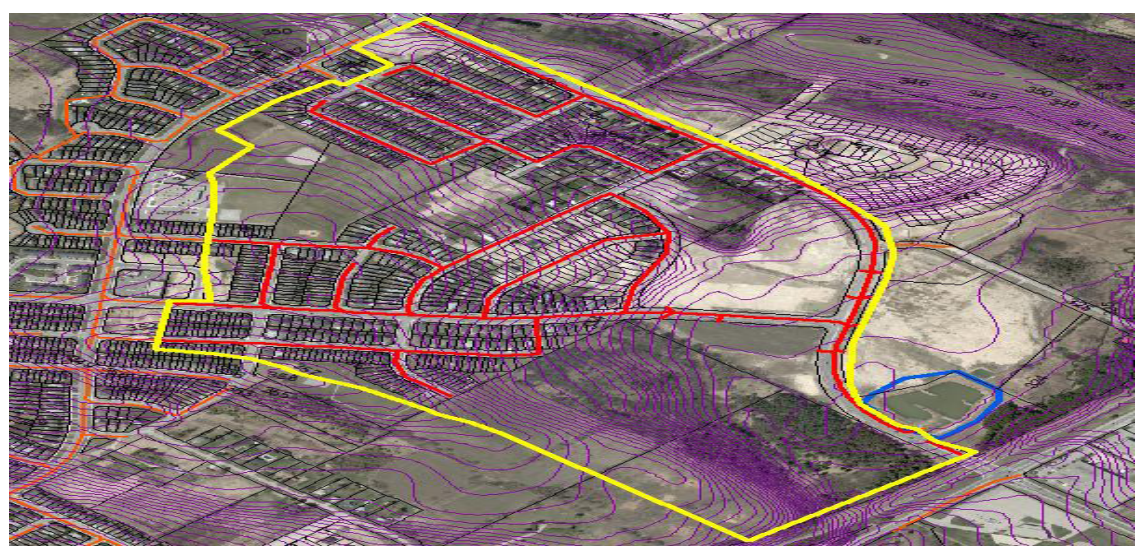

Figure 12.4 Pond 33 drainage area.

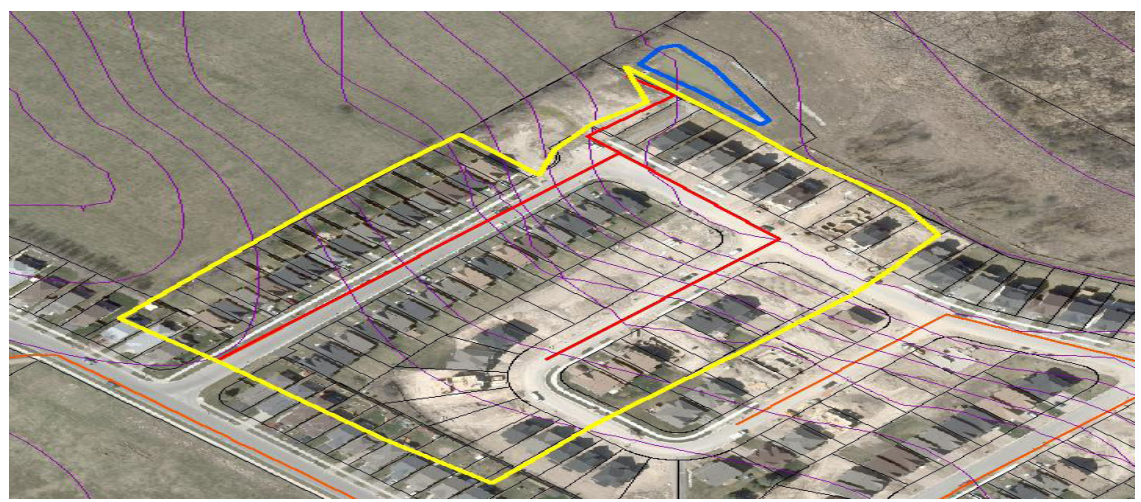

Figure 12.5 Pond 81 drainage area. 


\subsubsection{Monitoring and Data Collection}

The water temperatures were measured in sensitive zones of the ponds, such as the inlet, inside the pond, the outlet, and in the cooling trench. The sensors used for temperature and water level were $\mathrm{HOBO}$ pendant temperature sensors and HOBO U20 water level loggers respectively. The sensor locations and periods of record for water temperatures and water levels for pond 74 are presented in Table 12.3, as an example. Figure 12.6 shows a typical day's data for pond 74 .

Table 12.3 Pond 74 sensor locations and periods of record.

\begin{tabular}{|c|c|c|c|c|}
\hline Location & Measured & $\begin{array}{c}\text { Period of record } \\
2011 \\
\end{array}$ & $\begin{array}{c}\text { Period of record } \\
2010 \\
\end{array}$ & $\begin{array}{c}\text { Period of record } \\
2009 \\
\end{array}$ \\
\hline Inlet & Water level \& Temp. & $20110511-1020$ & $201004011-1109$ & $20090625-1022$ \\
\hline Outlet MH & Water level \& Temp. & $20110511-1020$ & $20100526-1109$ & $20090625-1022$ \\
\hline Inside Pond & Water level \& Temp. & $20110511-1020$ & $20100401-1109$ & $20090818-1022$ \\
\hline Water temp. $0 \mathrm{ft}$ & Temperature & $20110511-1020$ & $20100430-0926$ & $20090625-1022$ \\
\hline Water temp. $2 \mathrm{ft}$ & Temperature & $20110511-1020$ & $20100430-0926$ & $20090625-1022$ \\
\hline Water temp. $4 \mathrm{ft}$ & Temperature & $20110511-1020$ & $20100430-0926$ & $20090625-1022$ \\
\hline Water temp. $6 \mathrm{ft}$ & Temperature & $20110511-1020$ & $20100430-0926$ & $20090625-1022$ \\
\hline Outlet MH & Temperature & $20110511-1020$ & $20100526-0926$ & \\
\hline $\begin{array}{l}\text { Cooling Trench } \\
\text { Out }\end{array}$ & Temperature & $20110511-1020$ & $20100430-0926$ & $20090625-1022$ \\
\hline Cross street & Temperature & & $20100430-0926$ & $20090625-1022$ \\
\hline In manhole & Barometric pressure & $20110511-1020$ & $20100430-1109$ & $20090625-1022$ \\
\hline
\end{tabular}

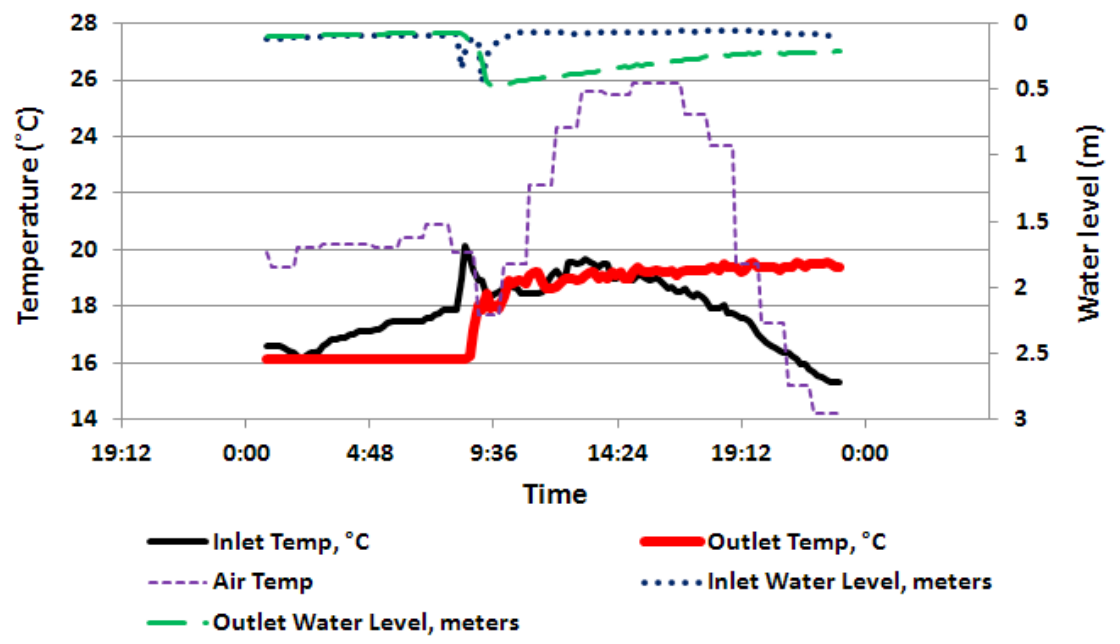

Figure 12.6 Pond 74 data 20100711 rain event. 
Details on monitoring for the rest of the ponds are not presented here but the data for the sensitive zones were collected as described above. Water level loggers (such as sensor installed inside the pond and outlet manhole) collected the depth of water. The measured depth then used to calibrate the PCSWMM model along with storage curve of the ponds.

\subsubsection{PCSWMM Modelling}

The collected data were used to establish a PCSWMM model to represent the existing hydrologic conditions of the catchments in the Guelph and Kitchener areas. The land uses within the catchments are varied from pond to pond (residential, parking lot, combination of residential and grassland). The drainage areas also vary in size, being between 5 ha and 79 ha. The model was developed from the photogrammetric data and AutoCAD maps representing the studied areas with the use of GIS tools.

The pond water level data were used to calibrate the PCSWMM model for existing conditions and the inflow and outflow extracted from PCSWMM was used to calculate the event mean temperature in different zones of the system which are inlet, pond water temperature close to outlet, outlet, and cooling trench. Figure 12.7 displays the PCSWMM results for two events versus the observed values for pond water level.

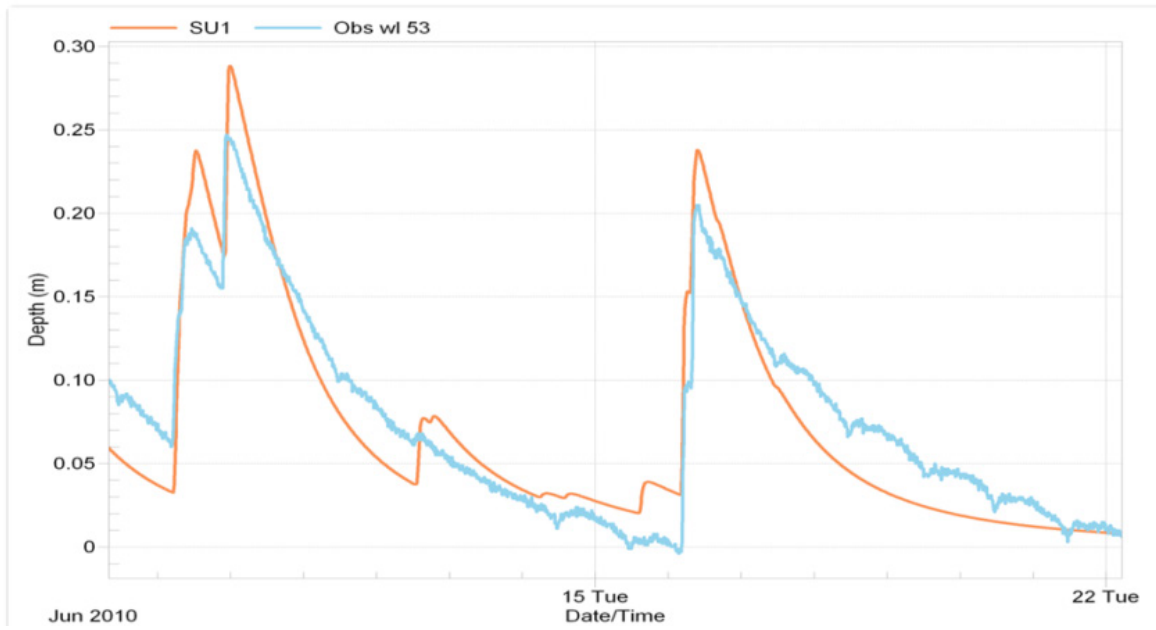

Figure 12.7 PCSWMM result vs observed values for pond 53. 


\subsection{Results and Discussions}

Section 12.2.1 presents results from a comparison of the inlet water temperatures for the Guelph ponds. Some discussion in regard to bottom draw outlet and cooling trenches performance and effectiveness are presented in sections 12.2.2 and 12.2.3

\subsubsection{Land Use Effect on Runoff Temperature}

Table 12.4 illustrates twelve rainfall events with different durations.

Table 12.4 Comparison of the inlet water temperatures.

\begin{tabular}{|c|c|c|c|c|c|}
\hline Date & Rainfall (mm) & Duration (h) & $\begin{array}{c}\text { Pond } 53 \\
20 \% \text { Imp. } \\
\text { DA }^{1} 79 \text { (ha) } \\
95 \mathrm{~m} \text { Pipe/ha }\end{array}$ & $\begin{array}{c}\text { Pond } 33 \\
50 \% \text { Imp. } \\
\text { DA } 19.4 \text { (ha) } \\
62 \mathrm{~m} \text { Pipe/ha }\end{array}$ & $\begin{array}{c}\text { Pond } 81 \\
60 \% \text { Imp. } \\
\text { DA } 4.9 \text { (ha) } \\
43 \mathrm{~m} \text { Pipe /ha }\end{array}$ \\
\hline 20090809 & 11.4 & 1 & 16.8 & 17.5 & 20.2 \\
\hline 20090817 & 21 & 1 & 17.3 & 18 & 19.9 \\
\hline 20100603 & 9.2 & 1 & 20.2 & 21.2 & 21.6 \\
\hline 20100715 & 10.2 & 2 & 21.1 & 25.1 & 25.3 \\
\hline 20100622 & 12.8 & 4 & 16.9 & 16.9 & 20.4 \\
\hline 20100627 & 43.8 & 5 & 20.3 & 22.8 & 22.9 \\
\hline 20100702 & 17.6 & 7 & 21 & 21 & 21.2 \\
\hline 20100709 & 19.2 & 7 & 22.1 & 24.4 & 22.9 \\
\hline 20100624 & 13 & 8 & 19.2 & 19.2 & 19.8 \\
\hline 20100606 & 18.4 & 9 & 16.7 & 19.3 & 17.4 \\
\hline 20100505 & 16 & 10 & 10.7 & 11.7 & 10.9 \\
\hline 20100626 & 9.6 & 10 & 18.4 & 20.3 & 20.3 \\
\hline
\end{tabular}

The following observations were made after examination of the information in Table 12.4:

lower inlet water temperature is observed when the percentage impervious cover is less (the drainage area of pond 53, which has $20 \%$ impervious area, shows a pronounced lower inlet water temperature in comparison with two other ponds); however, the large amount of pipe/ha may cause the lower inlet temperatures as well;

- lower inlet water temperature is observed when the length of the sewer pipe is longer;

shorter duration events tend to have more pronounced inlet temperature differences; and

a buried conveyance system could be designed to mitigate the heating effect of the upland area. 


\subsubsection{Thermal Enrichment in Ponds}

Thermal enrichment of all studied ponds is observed in the positive difference of outlet temperature from inlet temperature as is shown in Tables 12.5 and 12.6, for four ponds. The outlet event mean temperatures (EMTs) differences from inlet EMTs varied between $1.1{ }^{\circ} \mathrm{C}$ to $7.0^{\circ} \mathrm{C}$ which confirms the negative thermal impact of SWM Ponds.

Table 12.5 Ponds 33 and 53 calculated event mean temperatures.

\begin{tabular}{ccccccccc}
\hline \multirow{2}{*}{ Date } & $\begin{array}{c}\text { Rainfall } \\
\text { Em })\end{array}$ & $\begin{array}{c}\text { EMT rain } \\
\left({ }^{\circ} \mathrm{C}\right)\end{array}$ & \multicolumn{3}{c}{ Pond 33 EMTs $\left({ }^{\circ} \mathrm{C}\right)$} & \multicolumn{3}{c}{ Pond 53 EMTs $\left({ }^{\circ} \mathrm{C}\right)$} \\
& Inlet & Outlet & Difference & Inlet & Outlet & Difference \\
\hline 20100608 & 18.8 & 12.7 & 21.4 & 25.2 & 3.8 & 14.6 & 17.7 & 3.1 \\
20100616 & 11.4 & 13.8 & 15.1 & 22.2 & 7.0 & 16.0 & 20.2 & 4.2 \\
20100627 & 44.0 & 22.1 & 18.0 & 22.5 & 4.5 & 18.5 & 21.5 & 3.0 \\
20100723 & 33.5 & 25.4 & 19.5 & 25.4 & 5.9 & 18.4 & 23.6 & 5.2 \\
\hline
\end{tabular}

Table 12.6 Pond 74 and Church calculated event mean temperatures.

\begin{tabular}{ccccccccc}
\hline \multirow{2}{*}{ Date } & \multicolumn{2}{c}{ Rainfall } & EMT rain & \multicolumn{3}{c}{ Pond 74 EMTs $\left({ }^{\circ} \mathrm{C}\right)$} & \multicolumn{3}{c}{ Pond Church EMTs $\left({ }^{\circ} \mathrm{C}\right)$} \\
& $(\mathrm{mm})$ & $\left({ }^{\circ} \mathrm{C}\right)$ & Inlet & Outlet & Difference & Inlet & Outlet & Difference \\
\hline 20100709 & 12.8 & 21.0 & 22.0 & 26.4 & 4.4 & 20.8 & 25.1 & 4.3 \\
20100723 & 36.2 & 22.4 & 20.8 & 24.7 & 3.9 & 19.2 & 23.8 & 4.6 \\
20100821 & 19.2 & 19.2 & 21.8 & 22.9 & 1.1 & 20.4 & 22.9 & 2.4 \\
20100916 & 25.8 & 11.4 & 14.5 & 16.7 & 2.2 & 15.0 & 16.2 & 1.2 \\
\hline
\end{tabular}

\subsubsection{Bottom Draw Outlet Effectiveness}

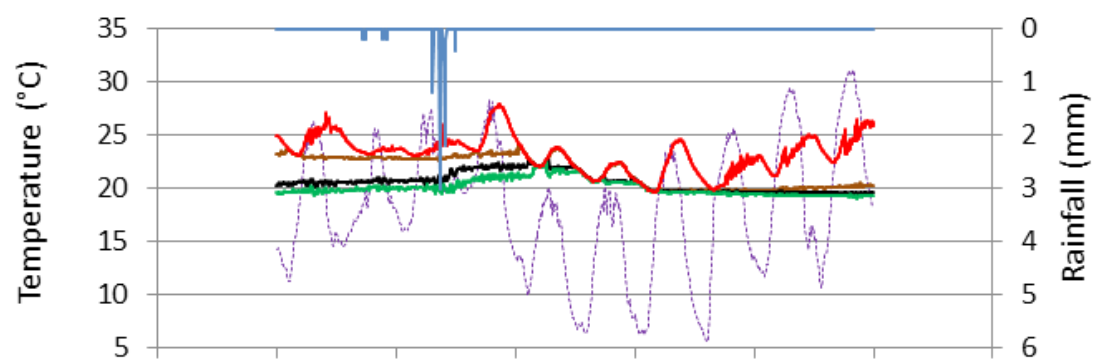

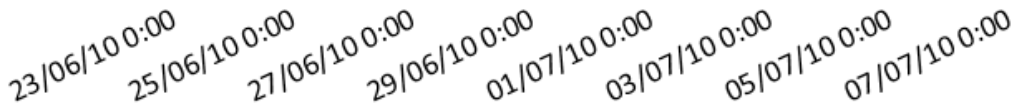

Date and Time

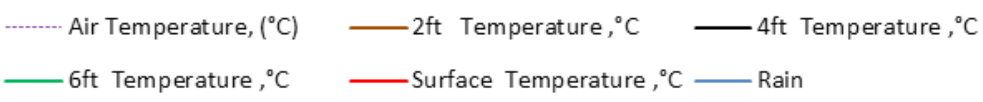

Figure 12.8 Water temperature at different depths of pond 74 . 
Notable points from observed data and calculated event mean temperature (EMT) for some events which are presented in Figure 12.5 above and Table 12.7 are as follows:

observed data confirm the cooling effect of the bottom draw outlet for pond 74 in Kitchener where all ponds have bottom draw outlets; and

- the significant difference in water temperature observed between the surface water temperature and that recorded at $90 \mathrm{~cm}$ (3ft) to $120 \mathrm{~cm}(4 \mathrm{ft})$. This can determine the minimum depth for bottom draw outlet design.

Table 12.7 Pond 74 calculated event mean temperatures for bottom draw and cooling trench.

\begin{tabular}{cccccccc}
\hline Date & $\begin{array}{c}\text { Rainfall } \\
(\mathrm{mm})\end{array}$ & $\begin{array}{c}\text { EMT } \\
\text { rain } \\
\left({ }^{\circ} \mathrm{C}\right)\end{array}$ & Inlet & $\begin{array}{c}\text { Bottom } \\
\text { Draw } \\
\text { Outlet }\end{array}$ & $\begin{array}{c}\text { Pond 74 EMTs }\left({ }^{\circ} \mathrm{C}\right) \\
\text { Outlet Dif- } \\
\text { ference from } \\
\text { Inlet }\end{array}$ & $\begin{array}{c}\text { EMT } \\
\text { Cooling } \\
\text { Trench }\end{array}$ & $\begin{array}{c}\text { Cooling Trench Dif- } \\
\text { ference from Outlet }\end{array}$ \\
\hline 20100709 & 12.8 & 21.0 & 22.0 & 17.6 & -4.4 & 17.5 & -0.1 \\
20100723 & 36.2 & 22.4 & 20.8 & 21.6 & 0.8 & 20.6 & -0.9 \\
20100821 & 19.2 & 19.2 & 21.8 & 21.1 & -0.7 & 20.7 & -0.4 \\
20100916 & 25.8 & 11.4 & 14.5 & 15.8 & 1.3 & 16.2 & 0.4 \\
\hline
\end{tabular}

Air temperature went down after event which may cause the graphs to converge. Also, there was no difference in water temperature at depth for several days which may have been due to groundwater influence to the bottom of the pond which did not measured for this study.

\subsubsection{Effectiveness of Cooling Trenches}

Pond 33, which has an infiltration trench, does not show any negative thermal impact on the water body. Good shading of the water body (Hanlon Creek) in the monitored areas and the good performance of the infiltration trench are the main reasons for this pond having no pronounced thermal impact.

Pond 53 has a well designed cooling trench. However, the performance of this cooling trench was not as expected since there were no or very few differences in water temperature between the pond outlet and the outlet of the cooling trench (as measured by the installed sensors). The weak performance of the cooling trench was partly due to a missing pipe cap at the very beginning of the pipe leading to the cooling trench and an upward overflow pipe at the end of the cooling trench, which together are supposed to provide the needed water head to help water infiltrate into the trench. Those missing parts caused the pipe to run free, so there was little time to equilibriate. 
Pond 81 has an infiltration trench which shows a cooling effect in dry periods or between events, which confirms the effectiveness of contact time between water and rocks inside the trench. However, no cooling effect was observed during the events. The main reasons for no cooling effect during the rainfall events could be (i) no shading and top soil cover for the trench; (ii) the small volume of the trench which could not hold adequate water to provide enough contact time for transferring heat from water to rocks and the surrounding soil; and (iii) the high temperature of the rocks and the initial water in the cooling trench, both of which are exposed.

Pond 74 has a well performing bottom draw outlet structure. It was found that the effectiveness of the bottom draw outlet in driving cooler water to the receiving system is much greater than the effectiveness of the cooling trench during rainfall events. Furthermore, the combination of a bottom draw outlet, the cooling trench and the interaction with the groundwater may help to give greater performance for this pond, with no thermal impact on the receiving system during the warm weather of summer.

Church pond has a very big cooling trench (90 m long) which has an interaction with ground water, and is well shaded. As a result, no negative thermal impact was observed during the course of the study from this cooling trench to the water body.

There are several factors which influence the effectiveness of cooling trenches, such as groundwater interaction and the dimensions of the trench. For instance, the ponds 74 and Church pond cooling trenches have groundwater interactions; the relatively high efficiency of these cooling trenches may partly result from this interaction. Design aspects of cooling trenches are another important factor on cooling trench performance. For example, the dimensions of the Church pond cooling trench are $90 \mathrm{~m}$ long and $>2 \mathrm{~m}$ deep, resulting in the best performance of all the cooling trenches studied. Although pond 74 has a big cooling tunnel (60 $\mathrm{m}$ long and $2 \mathrm{~m}$ deep), less ground water interaction may result in less cooling effect.

In regard to the monitored receiving systems, water temperature of the Clythe Creek (in Guelph, near pond 53) is mostly $>19^{\circ} \mathrm{C}$ during the summer (2010) according to data from installed sensors in the creek up and downstream of the pond, and this might have negative impact on the creek habitats.

\subsection{Conclusions}

This study confirms the influence of impervious percentage cover on inlet water temperature of stormwater management ponds as well as the cooling effect of sewer pipe systems on inlet water temperature; lower inlet water 
temperatures are observed when the length of the sewer pipe is greater. Therefore, the presence of a buried conveyance system can partially mitigate the warming effect of the drainage area.

Thermal enrichment of ponds is confirmed (refer to Tables 12.5 and 12.6).

Investigation of the effects of event duration confirms that shorter duration events tend to have more pronounced inlet temperature changes.

Air temperature has a big influence on average runoff temperature increases; and rainfall magnitude has a limited influence on average runoff temperature increases from the pond.

Observed data confirm the cooling effect of the bottom draw outlet; especially when the depth of bottom draw is $90 \mathrm{~cm}$ to $120 \mathrm{~cm}$. This can determine the minimum depth for bottom draw outlet design.

There are several factors which have influence the effectiveness of cooling trenches, such as groundwater interaction and the dimensions of the trench. For instance, the pond 74 and Church pond cooling trenches have groundwater interactions. Therefore, the relatively high efficiency of these cooling trenches may partly be a result of this interaction. The design aspects of cooling trenches are another important factor on cooling trench performance. For example, the dimensions of the Church pond cooling trench are $90 \mathrm{~m}$ long and more than $2 \mathrm{~m}$ deep, resulting in the best performance of all cooling trenches studied. Although pond 74 has a big cooling tunnel, $60 \mathrm{~m}$ long and $2 \mathrm{~m}$ deep, less ground water interactions may cause less cooling effects from this cooling tunnel. Another important factor in order to get the best result out of designed and constructed facilities is the maintenance of the facilities to make sure they are working properly.

In summary, the cooling trench performance is highly dependent on the following variables:

flow rate into the cooling trench;

runoff and cooling trench volumes;

influent temperature;

volume of water in the cooling trench before runoff; and groundwater interaction.

\section{Acknowledgments}

Special thanks go to the City of Guelph, the City of Kitchener, the Grand River Conservation Authority, and AECOM for their support and assistance in collecting the data and providing reports on ponds. 


\section{References}

Anderson, B., W. Watt, and J. Marsalek. 2002. Critical issues for storm-water ponds: Learning from a decade of research. Diffuse/Non-point Pollution and Waterhsed Management, 45(9), 277-283

Armour, C. L., 1991. Guidance for evaluating and recommending temperature regimes to protect fish.

Booth, D. B. and B. P. Bledsoe. 2009. Streams and urbanization. Chapter 6, 93-123.

Herb, W.R., Mohseni, O., Stefan, H.G., 2009. Simulation of temperature mitigation by a stormwater detention pond. J.Am.Water Resour.Assoc. 45, 1164-1178.

Lieb, D.A., Carline, R.F., 2000. Effects of urban runoff from a detention pond on water quality, temperature and caged Gammarus minus (Say)(Amphipoda) in a headwater stream. Hydrobiologia. 441, 107-116.

Marsalek, J., Q. Rochfort, L. Grapentine, and B. Brownlee. 2002. Assessment of stormwater impacts on an urban stream with a detention pond. Water Science and Technology, 45(3), 255-264

Picksley, W. and A. Deletic. 1999. "The Thermal Enrichment of Storm Runoff from Paved Areas - a Statistical Analysis." Journal of Water Management Modeling R204-07. doi: 10.14796/JWMM.R204-07.

Schueler, T. R. and J. Galli. 1992. Environmental impacts of storm-water ponds. Watershed Restoration Source Book

Selong, J. H., T. E. McMahon, A. V. Zale, and F. T. Barrows. 2001. Effect of temperature on growth and survival of bull trout, with application of an improved method for determining thermal tolerance in fishes. Transactions of the American Fisheries Society, 130, 1026-1037

Thompson, A., T. Wilson, J. Norman, A. Gemechu, and A. Roa-Espinosa. 2008. Modeling the Effect of Summertime Heating on Urban Runoff Temperature1. JAWRA Journal of the American Water Resources Association, 44(6), 1548-1563 
